Chemosphere, Vol.19, Nos.10/11, pp 1499-1502, 1989 Printed in Great Britain
$0045-6535 / 89 \$ 3.00+.00$ Perqamon Press plc

\title{
DECHLORINATION OF PERCHLORINATED AROMATIC COMPOUNDS BY GRAPHITE-POTASSIUM-INTERCALATE
}

\author{
M. Lisse1*, J. Kottmann \\ Fakultät für Chemie, Universität Bielefeld, \\ Postfach 8640, D-4800 Bielefeld 1 \\ D. Lenoir* \\ Lehrstuhl für Okologische Chemie und Geochemie, Universität Bayreuth, \\ Postfach 101251, D-8580 Bayreuth
}

Abstract: Potassium-graphite-intercalate (CoK) completely dechlorinates perchlorinated aromatic compounds in a few minutes. Beside preparative utilizations we found the reaction applicable for the degradation and detoxification of chlorinated compounds.

Perchlorinated aromatic compounds were used as agrochemicals, preservatives, polymer additives and in some technical processesi. As typical examples the following compounds should be cited; hexachlorobenzene (HCB)2, pentachlorophenol $(\mathrm{PCP})^{3}$ decachlorobiphenyl ether 1 and decachlorobiphenyl 2 :<smiles>Clc1c(Cl)c(Cl)c(Oc2c(Cl)c(Cl)c(Cl)c(Cl)c2Cl)c(Cl)c1Cl</smiles><smiles>Cc1c(Cl)c(O)c(Cl)c(Cl)c1Cl</smiles>

CI<smiles>Clc1c(Cl)c(Cl)c(Cl)c(Cl)c1Cl</smiles>

HCB 
Besides the technical production of chloroarenes and the distribution into the field of application some of these compounds are emitted into the environment without purpose; e.g. chlorinated dibenzodioxins and dibenzofurans are formed during incineration and metallurgic processes and are mainly emitted by the exhaust gases'. The two perchlorinated compounds octachlorodibenzodioxin $(O C D D)^{6}$ and octachlorodibenzofuran $(O C D F)^{6}$ are given as examples.<smiles>Clc1c(Cl)c(Cl)c2c(c1Cl)Oc1c(Cl)c(Cl)c(Cl)c(Cl)c1O2</smiles>

OCDD<smiles>Clc1c(Cl)c(Cl)c2c(oc3c(Cl)c(Cl)c(Cl)c(Cl)c32)c1Cl</smiles>

OCDF

Potassium graphite intercalate, $C_{8} K$, has been shown to be a useful and efficient reducing agent in reactions like reductive dimerization of diketones $^{\theta}$ and stereospecific debrominations ${ }^{9}$. We described earlier, together with collegues from Israel, the reductive cleavage of aryl-o- and aryl-cl-bonds with this reagent10.

In order to develop an easy chemical method of detoxification of perchlorinated aromatic compounds we have investigated the potassium graphite intercalate $C_{8} R$ as reductive agent for the above mentioned compounds.

The reaction of decachlorobipheny 2 with potassium graphite intercalate under our conditions gave biphenyl as reduction product. The progress of the reaction was detected by gas chromatography. After one minute only mono and dichlorinated biphenyl could be found in the reaction mixture, these products were further reduced and after 30 minutes biphenyl was found as sole reduction product:<smiles>Clc1c(Cl)c(Cl)c(-c2c(Cl)c(Cl)c(Cl)c(Cl)c2Cl)c(Cl)c1Cl</smiles>
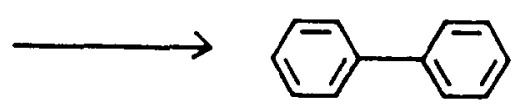

2

The reduction of octachlorodibenzodioxin, for example, is carried out under our standardized conditions. After one minute at $20^{\circ} \mathrm{C}$ neither ocDD nor other chlorinated dibenzodioxins could be detected by GC/MS analysis but the 
unsubstituted dibenzodioxin was detected. $98 \%$ of the theoretical amount of chloride anions was found by ion chromatography. The heterocyclic skeleton gave in $45 \%$ overall yield the products shown in the scheme:<smiles>Clc1c(Cl)c(Cl)c2c(c1Cl)Oc1c(Cl)c(Cl)c(Cl)c(Cl)c1O2</smiles><smiles>Oc1ccccc1Oc1ccccc1</smiles><smiles>Oc1ccccc1</smiles>

No other products like polymers were present in the reaction mixture, but the fate of half of the material could not be clarified.

All perchlorinated compounds are easily and completely dechlorinated within a few minutes at room temperature. The results are summarized in Table I.

Table I. Treatment of Perchloroarenes with $\mathrm{C}_{8} \mathrm{~K} / \mathrm{THF}$ at $20^{\circ} \mathrm{C}$ Chloroarene

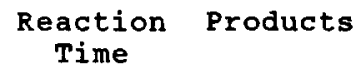

\begin{tabular}{|c|c|c|}
\hline $\mathrm{HCB}$ & $30 \mathrm{~min}$ & $\begin{array}{l}\text { no products detectablea: } \\
96 \% \text { chloride }\end{array}$ \\
\hline PCP & $30 \mathrm{~min}$ & phenol; $93 \%$ chloride \\
\hline $\begin{array}{l}1 \\
1 \\
1 \\
1\end{array}$ & $\begin{array}{r}5 \text { min } \\
15 \text { min } \\
60 \mathrm{~min} \\
300 \mathrm{~min}\end{array}$ &  \\
\hline $\begin{array}{l}\text { OCDD } \\
\text { OCDD }\end{array}$ & $\begin{array}{r}1 \mathrm{~min} \\
60 \mathrm{~min}\end{array}$ & $\begin{array}{l}\text { no dioxins detectabled } \\
\text { 2-hydoxybiphenyl ether, phenol } \\
\text { catechol; } 98 \% \text { chloride }\end{array}$ \\
\hline OCDF & $30 \mathrm{~min}$ & $\begin{array}{c}\text { 2-hydroxybiphenyl ether, DBF } \\
95 \% \text { chloride }\end{array}$ \\
\hline 2 & $30 \mathrm{~min}$ & biphenyl, $98 \%$ chloride \\
\hline
\end{tabular}


Typically, the preparation of the intercalate and the reduction are carried out as follows. $1.8 \mathrm{~g}$ graphite and $0.75 \mathrm{~g}(19 \mathrm{mmol})$ potassium were stirred under an argon atmosphere and heated to $150^{\circ} \mathrm{C}$. After $15 \mathrm{~min}$ at this temperature the brown graphite potassium intercalate was formed. At room temperature a solution of $108 \mathrm{mg}(0.24 \mathrm{mmol})$ octachlorodibenzodioxin in $50 \mathrm{ml}$ THF was added. The mixture was stirred for $120 \mathrm{~min}$. For work-up the mixture was treated with water and acidified with dilute nitric acid. Filtration and evaporation of the filtrate gave an oil which was dissolved in ether and water. The organic phase gave $19 \mathrm{mg}$ of a mixture of products mentioned in scheme 3 . The chloride content of the water phase was $98 \%$ of the theoretical value.

In comparision with other non-thermal methods ${ }^{4}$ our procedure has several advantages for the degradation of laboratory wastes: (I) the reduction with $\mathrm{C}_{\mathrm{B}} \mathrm{K}$ is quantitative at room temperature, (II) it is the most simple and convenient one.

\section{References}

1. Lehrbuch der Okologischen Chemie: Grundlagen und Konzepte für die ökolo gische Beurteilung von Chemikalien, Hrsg. F. Korte, 2. Aufl., ThiemeVerlag, Stuttgart, 1987.

2. Ullmann's Encyclopedia of Industrial Chemistry, $5^{\text {th }}$ edit., Vol. A6, VCH Verlag, Weinheim, 1986.

3. Umweltchemikalie Pentachlorphenol, Hrsg. Umweltbundesamt, E. Schmidt Verlag, Berlin, 1987.

4. (a) Polychlorierte Biphenyle, Hrsg. H. Lorenz und G. Neumeier, MMV Verlag, München, 1983.

(b) D. G. Ackerman, L. L. Scinto, P. S. Bakshi, R. G. Delumyea, R. J. Johnson, G. Richard, A. M. Takata and E. M. Swarzyn, Destruction and Disposal of PCB's by thermal and non-thermal methods, Noyes Data Cor poration, Park Ridge, New Jersey, 1983.

5. O. Hutzinger und H. Fiedler, Chemosphere, in press.

6. Formation of Dioxins and related Compounds in Industrial Processes, Nato Report No. 173, 1988 .

7. D. Savoia, C. Trombini and A. Umani-Ronchi, Pure Appl. Chem. 57, 1887 (1985).

8. D. Tamarkin, M. Rabinovitz, Synth. Metals 9 (1984) 125.

9. M. Rabinovitz, D. Tamarkin, Synthetic Commun. 14 (1984) 377.

10. M. Lissel, J. Kottmann, D. Tamarkin and M. Rabinovitz, Z, Naturforsch. 43b, 1211 (1988).

(Received in Germany 11 July 1989; accepted 2 August 1989) 